\title{
AGENDA SETTING BY THE MALAY ONLINE NEWSPAPERS DURING THE SEMENYIH BY-ELECTION
}

\author{
Muhamad Mat Yakim1 \\ Department Multimedia, Universiti Utara Malaysia. \\ (Email: muhamad.my@uum.edu.my) \\ Shafizan Mohamed ${ }^{2}$ \\ Department of Communication, International Islamic University Malaysia. \\ (Email: shafizan@iium.edu.my) \\ Kamaruzzaman Abdul Manan ${ }^{3}$ \\ Department of Communication, International Islamic University Malaysia. \\ (Email: kamarule@iium.edu.my)
}

Received date: $28-11-2019$

Revised date: $19-12-2019$

Accepted date: $20-12-2019$

Published date: 29-12-2019

To cite this document: Yakim, M. M., Mohamed, S., \& Manan, K. A. (2019). Agenda Setting by The Malay Online Newspapers During the Semenyih By-election. International Journal of Law, Government and Communication, 4(17), 121-131.

DOI: $10.35631 / \mathrm{ijlgc} .4170012$

\begin{abstract}
Media can play an important role in the public's voting decision. In Malaysia, Facebook the one of the most popular social media used in political communication. In relation, this paper investigates whether online news shared on Facebook set the political agenda for its readers. The Semenyih by-election offered an interesting case to study this relationship. In response to the importance of social networking sites as sources of information, news media organizations have set up Facebook channels in which they publish news stories or links to articles. This allows for wider news reach as well as audience participation. When audience members read and subsequently comment on news articles on Facebook, it becomes possible to identify public opinions and sentiments on the issues being covered. Content analysis was done on 300 issues highlighted by two Malay online news Facebook pages namely Malaysiakini BM and Sinar Harian during the Semenyih by-election. A total of 691 user issues were sampled to investigate whether user issues mirror the issues and sentiments presented in the news articles. The descriptive findings showed that news sentiments and audience sentiments are almost similar but did not exactly match.
\end{abstract}

Keywords: Facebook, Election, Politics, Public Opinion, Agenda Setting

\section{Introduction}

In the era of traditional media, there were limited numbers of media outlets. At the time, the agenda set by the media was able to reach wide-ranging of audiences and significantly influence the public agenda. This scenario is in contrast with the present social media 
environment where there are far more media sources. Each media competing with one another by tailoring the media content to suit their audience interests and thus threatening the long-held ability of the mass media to shape the public agenda (McCombs, 2015).

This shift from broadcasting to large audiences to a more narrowly targeted and attentive audiences is also known as audience fragmentation. Audience fragmentation is believed to be the fundamental reasons for the change in political behavior and public opinion. Feezell (2018) argued that the various online media that discuss political issues from different contexts could lead to diverse agendas among the public. Consequently, if the public does not share the media's agenda, it may be difficult to unite and engage in collective action. This leads to the question on whether the social media is able to reach and inform the general public and build mutual agreement on important issues.

Social media is an important form of political communication in today's elections (Salman, et al., 2018). The social media offers wide range of up-to-date information allowing people to learn and make comparisons between the political issues debated by political candidates. Additionally, social media allows voters to contribute and respond openly and share their opinions easily allowing the media to become a democratic agent of information. This study attempts to contribute to the understanding of the role of social media in political communication by investigating the agenda setting function of online news that are shared on Facebook.

\section{Literature Review}

Social media platform, especially Facebook, is a prominent 'information centre' for Malaysians, especially during the 14th General Elections campaign. Most Malaysians use Facebook to communicate casual and important discussion including political communication (Mohamed, Manan and Ghazali, 2019). Facebook provides a public sphere for people to express their political participation freely and without pressure. Moreover, given the high response makes Facebook serves as the most influential tool for the broadcast, online or print mainstream media to disseminate the latest news or live.

\section{Malaysians on Facebook}

Malaysians are generally Facebook savvy. With a population of 31.2 million, the country has some 16 million Facebook users (MCMC, 2017). The popularity of social networking sites (SNSs) such as Facebook was made possible by the improved Internet backbone, increase in Internet penetration and overall better utilization of Information Technologies in terms of mobile phones, computers and Internet access (Wok and Mohamed, 2017). Overall, Internet usage amongst individuals in Malaysia increased from 57 percent in 2013 to 71.1 percent in 2015, although the digital divide between rural and urban areas remains significant in states such as Sarawak, Sabah, Negeri Sembilan and Perak (Lee, 2017).

A 2016 study on the usage of social networking sites conducted by the Malaysian Communication and Multimedia Commission (MCMC) found that Malaysians access Internet very frequently ( $86.6 \%$ at least once a day) and is very participative in social networking sites $(84.3 \%)$ most primarily, Facebook. The study found that 96.5 percent of Internet users surveyed owned at least a Facebook account and 53.8 percent of the Internet users accessed Facebook on a daily basis.

The survey by MCMC also found that some $18.3 \%$ percent of social media users share political views. While the percentage of social media users sharing political views may not be 
that high, it is still a significant source of information for those who access it (90.1\%). 86.9\% of those who surveyed identified that social media is one of the main online information portals for them. A study on political engagement among Malaysian voters by Salman et al. (2018) supports the centrality of SNS in Malaysian political discourse. The study found that $63.5 \%$ of voters identifies SNS as their main source for political information with $86.5 \%$ claiming Facebook as their main SNS platform.

\section{The Malay Newspapers}

Malay newspapers are central to the life of many Malaysians, especially to the majority Malays. Most of the Malay newspapers have a long history and had been established even before Malaysia's independence in 1957. Language is not the only factor to define the direction of these newspapers; political ideologies play an important role too. Malay newspapers have been reported to give high coverage on political issues, especially during election period. For example, a study by Sani (2014) during the 2013 General Election stated that Berita Harian and Berita Minggu provided the highest coverage during the campaign period with a total of 1138 articles. Their coverage was found to favour on the BN coalition. This is in contrast to the more restricted Malay newspaper, Sinar Harian which claimed to provide a more neutral and balanced coverage when reporting political issues. Although Sinar Harian was first circulated in Terengganu and Kelantan, it was later distributed in Selangor in 2007 making it more popular among Malays in the urban and rural areas (Sani, 2014). The survival of the Malay newspapers has traditionally been determined by their affiliations with political actors who sponsor their operations and have control over their contents. Malay newspapers in Malaysia are relatively less independent as compared to Chinese-language newspapers (Chia, Fong and Neo, 2016).

This slowly changed when Internet came into picture. When media organisations started to adopt online platform as the avenue to gain more readerships, the Malay newspapers joined the bandwagon. Being online allowed these much-controlled newspapers to become more progressive by allowing for readers' contribution through opinion letters and reader comments. New online newspapers such Malaysiakini BM and the Malay edition of Free Malaysia Today (FMT) were much bolder in their news coverage and were competing with the traditional newspapers that also have a very strong presence online. When Pakatan Harapan took over the government in 2018, the new minister of Multimedia and Communication, YB Gobind Singh promised to guarantee the freedom of media (Sivanandam, 2018). This liberalized policy over the media is further changing the content of Malay newspapers, allowing them to become a more credible press rather than simply a political mouthpiece. By looking at this scenario, Malay newspapers are worth to be included in the study of this kind since they serve as information providers as well as platforms for discussing issues of public importance.

All the Malay newspapers in Malaysia operate actively on Facebook. They do so mainly because it is legally and politically more conducive for them to engage with the readers on SNS where the government cannot assert its full control. The mainstream newspapers that have direct link to the old government do not have a comment section in their online news portal. This is to avoid negative and controversial user discussions. However, when extending their news stories on Facebook and allowing for user comments, these newspapers are able to technically defy the imposed self-censorship and allow readers to interact. Therefore, the Facebook pages of Malaysian newspapers are definitely more alive and popular when compared to their online sites. 
The political discourse that went on during the weeks going into the $14^{\text {th }}$ General Election is a testament to the popularity of the Facebook pages of local newspapers. Every news article that relate to the election was responded with high volume of user shares and comments. In the comment sections, the users were unabashed and were very daring in sharing their opinions despite the still strict media environment. The sentiments shared by the users at the time were quite cohesive and presented an obvious public opinion. However, no careful study had captured the public opinion that was forming in the comment sections of the Facebook pages of the local newspapers at the time.

Interestingly, less than a year after the historic $14^{\text {th }}$ General Election that saw a change in the federal government, Malaysia had experienced 5 by-elections. In addition to general elections, a by-election occurs when a particular seat in the lower house of the parliament becomes vacant when, a member of parliament (MP) dies or is disqualified from being a member of the parliament. In each of this election, the Facebook pages of the Malaysian newspapers were alive with continuous stream of news coverage and an overwhelming user comment. It is interesting to look at how the users are discussing about the election and how they identified with the issues around the elections.

\section{The Semenyih By-election}

The Semenyih by-election is the sixth by-election after the 14th Malaysia General Elections. The election was held following the death of the state assemblyman, Bakhtiar bin Mohd Nor. The by-election was held on March 2, 2019. Bakhtiar was a member of Parti Pribumi Bersatu Malaysia, a coalition of the Pakatan Harapan (Malaysiakini, 2019). The total registered voters are 53,257 and majority of voters in Semenyih Malay. Thus, the study selected two main online Malay newspaper namely; Malaysiakini BM and Sinar Harian as a sample to study Semenyih by-election. This study seeks to understand: how online Malay newspaper uses Facebook in conveying an agenda-setting effect to shape the public agenda.

\section{Theoretical Framework: Agenda Setting}

Facebook comes with applications that make creating and sharing news becomes so easy. Moreover, with the smartphone, Facebook news sharing is fast and viral within seconds. This led to news organizations to publish their news via Facebook (Skogerb $\varnothing$ \& Krumsvik, 2015).

However, the fragmentation of Facebook audiences is the main challenge for news organizations in measuring how their agenda influence the public agenda. Nowak-Teter (2018) argue that public exposure to one political information is lower today because netizen was exposed to more political information via online. Media agenda capabilities in setting the public agenda have an important influence on policymaking. This is because what people believe important is heavily influenced by mass media.

Moreover, the Facebook audience is not passive. They react, interact and comments on each news post. Much positive feedback was received from the audiences that agreed with the agenda that been framed by the media. On the other hand, there was also a substantial amount of news that suffered from irrelevant, uncivil, and negative comments from the audience that not sharing the same viewpoint on the news issues (Mohamed, 2017).

According to Shafi and Vultee, (2018) Facebook comments is a new way of understanding the public agenda. By analyzing the sentiment of the comments, we could understand whether the public has positive or negative thinking about the issues published by the media. Agenda-setting offers a way to understand this relationship between news and public opinion. 
Undeniably, the volume and theoretical richness of research activity on Agenda setting have made it one of the most studied concepts in media effect research (Guo \& McCombs, 2005). The concept of agenda setting was innovated by Walter Lippmann (1922) in his famous book, "Public Opinion," where he posited the notion that the media construct public views of the world. Fifty years later, McCombs and Shaw conducted the seminal study of agenda setting. The central thesis of a 'first-level' Agenda-setting is the transfer of object salience from the mass media to the public (McCombs \& Shaw, 1972). It mainly focuses on the issues, events or political figures of the media agenda, and how the media agenda impacts audience perceptions about what issues are worthy of attention.

In other words, the amount of news coverage of an object would largely determine the perceived importance of that object by the audience. The level of importance or what McCombs (2005) referred to as salience indicate the transfer of influence from the media to the audience. To examine the effect of the media, agenda setting lists and compares the media's issue salience with the public's issue salience. The media's issue salience can be identified by studying the media news coverage while public's issue salience can be learned by asking the public about the issues that are important to them. Traditional methods of investigating whether news influences public agendas require comprehensive and sometimes complex field study wherein a public opinion survey becomes the prominent way to identify public sentiments. But with the availability of direct user comments on news, it becomes possible to look at how media users respond to news articles and whether they place the same level of issue salience when compared with the issues covered by the news media.

Based on the context of the elections and the theoretical propositions offered by Agenda setting, this study asks:

1. What are the issues covered by the Malay newspapers during the Semenyih By-election?

2. What are the slants used by the Malay newspapers during the Semenyih By-election?

\section{Methodology}

To answer the research questions two Malay newspapers, Malaysiakini (Bahasa Malaysia) and Sinar Harian were sampled. These newspapers were also selected because they have a very prominent online presence and represented diversity in readership. Malaysiakini (BM) iss mostly read by the more educated, urban and politically liberal demographic group (Lee, Nayan and Othman 2016). Sinar Harian readers were mainly from low to middle-class Malay readers (Lee et al. 2016). These variations in the demographic background of the readers were important in capturing a more comprehensive data that signified majority Malaysians political views.

Table1: Descriptions of the Sampled Newspapers

\begin{tabular}{l|l|l|l}
\hline Newspapers & $\begin{array}{l}\text { Number of } \\
\text { Facebook } \\
\text { Followers }\end{array}$ & $\begin{array}{l}\text { Total } \\
\text { newspaper } \\
\text { issues }\end{array}$ & $\begin{array}{l}\text { Total } \\
\text { commenters } \\
\text { issues }\end{array}$ \\
\hline Semenyih election & & & \\
\hline $\begin{array}{l}\text { Malaysiakini (Bahasa Malaysia) } \\
\text { Sinar Harian } \\
\text { TOTAL }\end{array}$ & 2.2 million & 204 & 389 \\
\cline { 2 - 4 } & 3.9 million & 194 & 302 \\
\cline { 2 - 4 } & & $\mathbf{3 9 8}$ & $\mathbf{6 9 1}$ \\
\hline
\end{tabular}


*the newspapers' number of Facebook followers were recorded on the first day of data collection

This study used content analysis to collect the data. It is a common method used in electoral studies especially when looking at Facebook usage among politicians (Manaf and Manan, 2017). Shafi and Vultee (2018) content analysed Facebook posts of presidential candidates Barack Obama and Mitt Romney during the $12^{\text {th }}$ American Presidential Primaries. The coding process was conducted during the formal campaign weeks that ran from March $2^{\text {nd }}$, 2019 to March $16^{\text {th }}, 2019$. A standardized codebook and code sheet were designed to suit the Facebook functions and categories. Each Facebook post was the unit of analysis while details of the post such as the media issues, media slant, public issues, and public slant were the variables. Two undergraduate students were coders trained on the materials by the researchers. Each coder was assigned with a newspaper and was asked to code 10 news articles on the 'PRK Semenyih' every day during the data collection period. This lasted for 15 days. Therefore, each coder worked on 150 piece of news article. Each article could generate up to 3 issues. Since the number of comments on each news article was very big, only the top 50 most relevant comments were coded. On Facebook, most relevant comments are comments that have the most likes and replies. Out of the 50 comments, only the top 5 issues discussed by the commenters were recorded.

The coding task was done using personal computers. The researchers also conducted a mock data collection. The coders were given four news articles and were required to capture the data and transfer the data into the code sheet. The mocked data were then analysed using Holsti's CR (1969) inter-coder reliability to test the trustworthiness of the findings. In general, the test result shown that all variable is above the minimum reliability value which is 0.7. All the data were recorded and analysed using the statistical software IBM SPSS software.

\section{Results}

Table 2 highlight the issues discussed by the Malaysiakini BM online news and their public. Based on the data generally, there is a similarity between the issues discussed such as both media $(40.1 \%)$ and public $(33 \%)$ most important issues are politics. Similarly, both media (4\%) and public (3.8\%) see political leadership as an important agenda. However, the rest of the issues are not similar. For instance, the second important issue portrayed by the media is political campaign (19.3\%) whereas for the public, Malay-Islam issues is more important $(21.3 \%)$.

Table 2: Top Ten Issues in Malaysiakini BM

\begin{tabular}{cccc}
\hline Media Agenda & Percentage & Public Agenda & Percentage \\
\hline Politics & 40.1 & Politics & 33.0 \\
Campaign & 19.3 & Malay-Islam & 21.3 \\
Social & 9.4 & Others & 14.6 \\
Election & 8.4 & Economy & 11.7 \\
Malay-Islam & 6.9 & Najib Razak & 6.3 \\
Local Issues & 5.9 & Social & 6.1 \\
Political Leadership & 4.0 & Political Leadership & 3.8 \\
Government & 2.5 & International Relation & \\
Administration & & & 1.1 \\
Economy & 2.0 & Campaign & 1.1 \\
Unity & 1.5 & Crime & 0.9 \\
\hline
\end{tabular}


In addition, there are issues that got less coverage by the media such as issues of the economy was ranked at number nine by the media (2\%) while the public ranked these issues in number four $(11.7 \%)$. An interesting point to note, even though media publish news related to Semenyih election, there were responses from the public that not related to the news such as the public discuss other issues (14.6\%). Moreover, issues of Najib Razak (6.3\%) who is not the candidate was also discussed evenhough the media did not publish about him.

Table 3 presents the comparison between message slants by the Malay Malaysiakini online news and its public. The data shows that Malaysiakini (28.8\%) and public (26.2\%) shared the same negative slant towards $\mathrm{PH}$.

Table 3: Top Ten Issues Slants By In Malaysiakini BM

\begin{tabular}{cccc}
\hline Media Slant & Percentage & Public Slant & Percentage \\
\hline Negative PH & 28.8 & Negative PH & 26.2 \\
Positive PH & 15.0 & Negative BN & 16.8 \\
Positive BN & 13.8 & Positive PH & 12.3 \\
Negative BN & 10.0 & Positive BN & 11.4 \\
Negative PAS & 9.4 & Positive BN/PAS & 9.9 \\
Positive BN /PAS & 6.3 & Negative DAP & 8.5 \\
Neutral PH & 5.6 & Negative BN/PAS & 6.0 \\
Negative BN /PAS & 5.0 & Negative PAS & 4.9 \\
Neutral BN & 3.1 & Positive Bersatu & 2.2 \\
Positive Bersatu & 3.1 & Positive PAS & 1.8 \\
\hline
\end{tabular}

In broad, the total media slant and public slant were also negative towards $\mathrm{PH}$ government and positive towards BN. This indicated that Malaysiakini's slant was able to influence public slant.

Table 4 presents the issues discussed by the Sinar Harian online news and their public. Based on the data, there is a similarity between the issues discussed by media and the public. However, in the context of the rank of important issues, only one similarity was found where the media $(1.8 \%)$ and the public $(0.4 \%)$ ranked local issues at the eight most important.

Table 4: Top Ten Issues In Sinar Harian

\begin{tabular}{cccc}
\hline Media Agenda & Percentage & Public Agenda & Percentage \\
\hline Election & 46.0 & Politics & 63.8 \\
Politics & 36.9 & Political & 13.4 \\
Campaign & 4.3 & Leadership & 10.8 \\
Government & 3.2 & Election & Najib Razak \\
Administration & & & 4.7 \\
Political & 2.7 & Malay-Islam & 2.6 \\
Leadership & 2.1 & Government & \\
Najib Razak & 1.6 & Administration & 2.2 \\
Development & 1.6 & Economy & 1.3 \\
Local Issues & 1.1 & Local Issues & 0.4 \\
Malay-Islam & 0.5 & Campaign & 0.4 \\
Crime & & Development & 0.4 \\
\hline
\end{tabular}


However, the rest of the rank of issues did not match. For example, the top issue by the media is election (46\%) but the public viewed politics (63.8\%) as the most significant issue to them. In addition, there are issues not covered by the media such as issues of the economy that was seen as important by the public $(1.3 \%)$.

Table 5 below shows that Sinar Harian online was positive towards PH (27.8\%) while its public top slant was negative towards $\mathrm{PH}(40.5 \%)$.

Table 5: Top Ten Issue Slants in Sinar Harian

\begin{tabular}{cccc}
\hline Media Slant & Percentage & Public Slant & Percentage \\
\hline Positive PH & 27.8 & Negative PH & 40.5 \\
Negative PH & 17.9 & Positive BN & 16.8 \\
Negative BN & 14.6 & Negative BN & 12.3 \\
Positive BN & 13.9 & Positive BN/PAS & 11.5 \\
Positive BN/PAS & 9.3 & Negative DAP & 7.0 \\
Neutral PH & 7.3 & Positive PH & 3.1 \\
Neutral BN & 4.0 & Positive PAS & 3.1 \\
Positive Bersatu & 2.6 & Positive Bersatu & 2.2 \\
Negative PAS & 2.0 & Negative PKR & 2.2 \\
Positive PKR & 0.7 & Negative BN/PAS & 1.4 \\
\hline
\end{tabular}

Sinar Harian was generally more positive towards $\mathrm{PH}$ which was contrary to its public that view PH government negatively. This data proposes that Sinar Harian's viewpoint and its public's opinion are not the same.

Table 6 present the top ten issues discussed by the Malaysiakini Malay and Sinar Harian and the issues highlighted by their public. Based on the data, there is a similarity between the issues discussed by both media and their publics. However, in the context of the rank of main issues, there is a significant difference between how media and public perceived the important issues. The only similarity is that both media $(39.1 \%)$ and public (44\%) saw politics as an important agenda.

Table 6: Top Ten Overall Issues Discuss by The Media and Their Public

\begin{tabular}{cccc}
\hline Media Agenda & Percentage & Public Agenda & Percentage \\
\hline Politics & 39.1 & Politics & 44.0 \\
Elections & 26.8 & Malay-Islam & 15.1 \\
Campaign & 12.2 & Others & 9.9 \\
Social & 4.9 & Economy & 8.2 \\
Malay-Islam & 4.2 & Political Leadership & 7.2 \\
Local Issues & 3.9 & Najib Razak & 5.8 \\
Political Leadership & 3.4 & Elections & 4.2 \\
Government & 2.9 & Social & 4.0 \\
Administration & 1.3 & Campaign & 0.9 \\
Development & 1.3 & Government & 0.7 \\
Najib Razak & & Administration & \\
\hline
\end{tabular}

As for the second important issues, media discussed more on elections (26.8\%) while the public were referring more to the Malay-Islam (15\%) issue. Only $4.2 \%$ of public discussion 
was about the elections. There are also issues that were highlighted by the media but were not catched on by the readers such as the local issues $(3.9 \%)$. On the other hand, there are also issues that were not highlighted by the media such as the economy $(8.2 \%)$ but is frequently discussed by the public. An interesting point to note is that even though media publish news related to Semenyih election, there are responses from the public that did not relate to the news. Interestingly also, issues related to Najib Razak (6.3\%) who is not the candidate were discussed by both the media $(1.3 \%)$ and public (5.8\%).

Table 7 describes the top ten of the news slants framed by the media and the corresponding public slants. In general, Malaysiakini Malay and Sinar Harian news slants are quite balanced. Both the Malay online news report positive and negative news about Pakatan Harapan (PH) government as well as the opposition. On the other hand, the public was more interested about Pakatan Harapan. This can be seen by how both media (23.5\%) and public $(32 \%)$ shared the same negative views of PH. In addition, both media (13.8\%) and public $(13.6 \%)$ have a common positive view of $\mathrm{BN}$ which were ranked as the third significant slant.

Table 7: Top Ten Message Slant by The Media and Their Public

\begin{tabular}{cccc}
\hline Media Slant & Percentage & Public Slant & $\begin{array}{c}\text { Percenta } \\
\text { ge }\end{array}$ \\
\hline Negative PH & 23.5 & Negative PH & 32.0 \\
Positive PH & 21.2 & Negative BN & 15.1 \\
Positive BN & 13.8 & Positive BN & 13.6 \\
Negative BN & 12.2 & Positive BN/PAS & 10.6 \\
Positive BN/PAS & 7.7 & Positive PH & 8.7 \\
Neutral PH & 6.4 & Negative DAP & 7.9 \\
Negative PAS & 5.8 & Negative BN/PAS & 4.2 \\
Neutral BN & 3.5 & Negative PAS & 3.4 \\
Negative BN/PAS & 2.9 & Positive PAS & 2.3 \\
Positive Bersatu & 2.9 & Positive Bersatu & 2.2 \\
\hline
\end{tabular}

The public appears to be unhappy with the PH government because most of their comments are negative towards PH (32\%) compared to negative BN (15.1\%). Most of the public were not happy because of PH government did not manage to fulfill most of the manifestos they promised during the $14^{\text {th }}$ general election. At the same time, the public is concerned about many issues pertaining to the Malays which they see as being neglected by the new government. This has led much public dissatisfaction with the PH government.

\section{Conclusion}

This study highlighted that during the Semenyih election, the Malay newspapers and their public were not focusing on the same main issues and not giving the same amount of significance to the issues. As such, the issue discusses by the newspapers were not match with their public issue. This indicates that even though the newspaper framing the issues of the news in such, but the public views the issues of the news differently. Moreover, the news commenters can relate these issues to public agreeing and disagreeing or even proposing a different idea shown the public opinion becomes stronger as a result of the growing popularity of social media. This brings into question whether the roles of news organizations as agenda setters that provide the public with information about issues and influencing public opinion is still relevant. However, the opinions of the commenters on issues were still related to the main topic of the news. Thus, this shapes the role of the news media less of agenda setters but more of a discourse centers. The news media is still an important source of news 
and distributors of agendas however, this study identified that the news commenters also play an important role in the agenda-setting process. Hence, it is worthwhile for future research to analyze the commenter's sentiment and how they influence and set the public agenda.

\section{References}

Chia, T. Y., Fong, Y. L., \& Neo, D. H. J. (2016). Framing Diplomatic Relations: A Comparative Analysis of Malaysian and Chinese Newspapers Coverage of Najib's Visit to China. SEARCH-Journal of The Southeast Asia Research Centre For Communications And Humanities, 8(2), 34-47.

Coleman, R., McCombs, M., Shaw, D. and Weaver, D. 2009. Agenda Setting. In the Handbook Of Journalism Studies, eds. K. Wahl-Jorgensen, K and Hanitzsch, T. 147160. New York: Routledge

Feezell, J. T. (2018). Agenda Setting through Social Media: The Importance of Incidental News Exposure and Social Filtering in the Digital Era. Political Research Quarterly. https://doi.org/10.1177/1065912917744895

Guo, L., \& McCombs, M. (Eds.). (2015). The power of information networks: New directions for agenda setting. Routledge.

Holsti, O. (1969). Content analysis for the social sciences and humanities. Reading, MA: Addison-Wesley.

Lee, C. (2017). Facebooking to Power: The Social Media Presence of Malaysian Politicians. ISEAS Perspectives 74:1-11.

Lee, K. T., Liana Mat Nayan and Siti Suriani Othman (2016) Kegunaan Dan Kepuasan Portal Berita Dalam Kalangan Belia Malaysia. Jurnal Komunikasi, Malaysian Journal of Communication 32(2): 790-816 Lee, K. T., Liana Mat Nayan and Siti Suriani Othman (2016) Kegunaan Dan Kepuasan Portal Berita Dalam Kalangan Belia Malaysia. Jurnal Komunikasi, Malaysian Journal of Communication 32(2): 790-816

Malaysiakini (2019). Semenyih by-election on March 2. Malaysiakini. 18 January 2019. Retrieved $9^{\text {th }}$ May 2019.

Lippmann, W. (1922) Public Opinion. New York: Macmillan.

Manaf, A. M. A., Taibi, M., \& Manan, K. A. (2017). Media agenda and public agenda: a study of issues during the 13th general election. Jurnal Komunikasi, Malaysian Journal of Communication, 33(2), 13-26.

MCMC (2018) Internet Users Survey 2018. Retrieved from https://www.mcmc.gov.my/skmmgovmy/media/General/pdf/Internet-Users-Survey2018.pdf

McCombs, M. (2005) A look At Agenda-Setting: Past, Present And Future. Journalism studies 6(4): 543-557.

McCombs, M. E. and Shaw, D. L. (1972) The Agenda-Setting Function Of Mass Media. The Public Opinion Quarterly 36(2): 176-187

Mohamed, Shafizan (2017) Breaking the Malaysian political media dichotomy: A case for citizen's media. International Academic Research Journal of Social Science, 3 (2). pp. $17-23$.

Mohamed, S., Manan, K. A. \& Ghazali, W.N.W (2019) Facebook Use and Personalization among Malaysian Politicians during the 14th Malaysian General Election. Forum Komunikasi, 14(1): 23-43

Nowak-Teter, E. (2018, January 19). Agenda-setting theory and the new media. Retrieved from https://www.researchgate.net/publication/322602862

Salman, A., Mustaffa, N., ... Ali, M. N. S. (2018). Social Media and Agenda Setting: Implications on Political Agenda. Jurnal Komunikasi, Malaysian Journal of Communication. https://doi.org/10.17576/jkmjc-2016-3201-19 
Sani, M.A.M., 2014. Malaysia's $13^{\text {th }}$ General Election: Political partisanship in the mainstream print media. Asia Pacific Media Educator, 24(1), 61-74.

Shafi, A., \& Vultee, F. (2018). One of Many Tools to Win the Election: A Study of Facebook Posts by Presidential Candidates in the 2012 Election. In Media Influence: Breakthroughs in Research and Practice (pp. 24-42). IGI Global.

Sivanandam, H (2018, May 22 ${ }^{\text {nd }}$ ) Media freedom will be a priority, says Gobind. TheStar Online. Retrieved from https://www.thestar.com.my/news/nation/2018/05/22/mediafreedom-will-be-a-priority-says-gobind

Skogerbø, E., \& Krumsvik, A. H. (2015). Newspapers, Facebook and Twitter: Intermedial agenda setting in local election campaigns. Journalism Practice, 9(3), 350-366.

Wok, S., \& Mohamed, S. (2017). Internet and social media in Malaysia: Development, challenges and potentials. In The Evolution of Media Communication. IntechOpen 